\title{
Impact of Organic Manure Combinations on Performance and Rot Infection of Stressed-Jerusalem Artichoke Plants
}

\author{
A.A. M.Awad" and Hoda M. H. Ahmed ${ }^{* *}$ \\ "Soil \& Natural Resources Department, Faculty of Agriculture \& Natural Resources, Aswan \\ University, Aswan 81528, Egypt. ${ }^{* *}$ Botany Department (Plant pathology), Faculty of Agricul- \\ ture, Fayoum University, Fayoum 63514, Egypt
}

\begin{abstract}
$\mathbf{T}$ HIS investigation was carried out for two summer seasonsof 2016/2017 and 2017/2018 to investigate the influence of three types of organic manures;farmyard (FYM),poultry (PLM) and pigeon manures(PGM) and their combinationson southern blight disease incidence (caused by Sclerotiumrolfsii), some vegetative growth characters, chemical constituents, yield and its components of Jerusalem artichoke (Helianthus tuberosus L.)plants grown under saline and calcareous soils. The results indicated that $\mathrm{T}_{8}(75 \% \mathrm{PGM}+25 \% \mathrm{FYM})$ treatment recorded the highest values for plant height, number of lateral shoots, number of leaves, leaf fresh and dry weights, stem fresh dry weights and leaf area plant ${ }^{-1}$ in 2016/2017 growth season.However, $\mathrm{T}_{2}(100 \%$ PLM) treatment showed the highest values for the previous characters except the number of leaves and leaf areaplant ${ }^{-1}$. Superior values were obtained by $\mathrm{T}_{4}(75 \% \mathrm{FYM}+25 \%$ PLM) followed by $\mathrm{T}_{3}(100 \% \mathrm{PGM})$ treatments regardingrelative chlorophyll content in both seasons.Treatments $\mathrm{T}_{9}(75 \% \mathrm{PGM}+25 \% \mathrm{PLM})$ for cadmium and $\mathrm{T}_{7}(75 \% \mathrm{PGM}+25 \% \mathrm{PLM})$ for nickel showed the lowest values of tuber Jerusalem artichoke in both seasons, in addition $\mathrm{T}_{3}\left(100 \%\right.$ PGM) and $\mathrm{T}_{4}(75 \% \mathrm{FYM}+25 \%$ PLM)treatments for lead content in 2016/2017 and $2017 / 2018$, respectively. The treatment $T_{2}$ had the highest significant reduction of the disease incidence(DI) percentage. While, the best treatment conferred highest leaf contents ofNPK, as well astuber fresh and dry weights, dry matter, and total yieldand lowest tuber content of nickel were $\mathrm{T}_{7}(75 \% \mathrm{PLM}+25 \% \mathrm{PGM})$ and tuber cadmium content was $\mathrm{T}_{9}(75 \% \mathrm{PGM}+25 \% \mathrm{PLM})$. The same treatment $\mathrm{T}_{7}$ had the highest significant reduction rate of DI and area under disease progress curves (AUDPC).
\end{abstract}

Keywords: Jerusalem artichoke,Organicmanure,Heavy metals,Sclerotiumrolfsii, Saline and calcareous Soil.

\section{Introduction}

Southern blight disease has a wide host range of agricultural and horticultural crops, forest trees and weeds, which is caused by the soilborne fungus; Sclerotiumrolfsii (Flores-Moctezumaet al., 2006). The fungus is distributed around the world in tropical and subtropical regions, as Africa, Asia,Australia and parts of Europe (Flores-Moctezuma et al., 2006). Southern blight is a limiting disease for Jerusalem artichoke production(Sennoi et al.,2010). Primarily, the disease was caused in warm climates, especially under high temperature with a humid condition (Kwon et al., 2008 and Sennoi et al., 2010). Whereas, Okabe et al. (2000) has grouped the S. rolfsii isolates according to ORF-ITSinto three groups; two of them were detected in warm temperature regions and one in a cool temperate region.

Certain publication concerning on sources of genetic resistance against $\mathrm{S}$. rolfsii. Where, the main pathogen management is depending on crop rotation (reducing sclerotia numbers in the soil) and subsequent disease incidence in susceptible crops (as the rotation of carrot with sweet potato or buckwheat (Jenkins and Averre, 1986), and peanut with bahiagrass or cotton (Johnson et al., 1999). Adding organic amendments such as oat straw (Gautum and Kolte, 1979) or cruciferous plants (Stapleton and Duncan, 1998) limits disease incidence and might be useful in controlling $\mathrm{S}$. rolfsii in small-scale agricultural systems. Whereas, Flores-Moctezuma et al. (2006) have found that

*Corresponding author: ahmed.abdelaziz@agr.aswu.edu.eg

DOI : 10.21608/ejss.2018.6151.1216

C2018 National Information and Documentation Center (NIDOC) 
by application of the three plant amendment (finely ground dried compost of Ficusmicrocarpa L., Coffeaarabica L. beans, and plant residues Partheniumhy sterophorus) individually was associated with increased damage and high sclerotial populations.

Due to continuous cropping and negligence of soil organic fertilizers, soil nutrient status may be improved by the use of organic fertilizerssuch as farmyard, poultry and pigeon manures with or without inorganic fertilizers (Dauda et al. 2008). In this respect, poultry manure is known as nutrient-richest (Enujeke et al. 2013), helping establish and optimize soil physical and chemical for plant growth.It is also essential for establishing and maintaining the optimum soil physical condition for plant growth.Scientists have been studied the beneficial effects of organic materials for plants, soils and environment. Modern farming system is heavily dependent on chemical fertilizers, creating. A wide range of problems is including depletion of fertilityand reducing crop yieldwhich reduces the yield year after year. Whereas,organic fertilizerscan improve the texture of different soil types (Mahmoud et al., 2009). However, excessive use ofchemical fertilizers maycontaminatethe environment, negatively affectingcrop plants and human health. In organic farming, the soil becomes rich in nutrients, resulting in healthy and pathogen-resistantcrop plants (Wakui, 2009). An integral use of organic and inorganic fertilizers may use for supplying of adequate nutrient quantities to improve crop productionand minimize environmental hazard impact John et al. (2004).

Soil salinization is proved to occur due to several reasons such as poor irrigation water with its poor management, over-irrigation that accumulates salts in the soil top layer, proximity to the sea, the capillarity riseof salts from underground water into the root zone due to excessive evaporation, low rainfall,high evaporation rate, and excessive use of chemical fertilizers (Rady et al., 2013).Salinization is spreading more rapidly in irrigated lands because of improper management of irrigation and drainage (FAO 2008). Salinity is one of the environmental problems, limiting soil productivity. It affects plants through osmotic effects making so-called "Physiological drought; Rady et al., 2013", ion specific effects and oxidative stress (Mansour et al., 2005).
High salinity levels are known to affect many physiological and metabolic processes, leading to plant growthrestriction (Sadeghi, 2010). Calcareous soils containing various levels of calcium carbonate cover a considerable portion of Agricultural lands in Egypt (about 0.65 million feddan $=0.27$ million hectare), particularly in the northwestern coastal zone and Sinai. They characterize by undesirable properties negatively affecting plant growth(Hassan, 2012). Therefore, this type of soil needs untraditional mean such as organic manure mixtures to overcome the undesirable soil properties(El-Hadyet al., 2010, 2012 a,b).

Jerusalem artichoke (JA; Helianthus tuberosus L.) is a native of North America.It has been grown in Europe since the $17^{\text {th }}$ century (Žaldarienè et al., 2012). JA is considered one of the important non-traditional vegetable crops that are newly introduced to Egypt for its high nutritional and medical values. However, growing of this crop is still limited in small areas. The aim of this study was to assess the influence of three different organicmanures(farmyard, poultry, and pigeon)on some growth characteristics, chemical constituents,yieldand disease severity of southern blight of Jerusalem artichokegrown under saline and calcareous conditions, and compared those impacts with the effect of chemical fertilizers.

\section{Material and Methods}

Experimental site and plant material

This study was conducted at 'Demo' Experimental Station Farm (29 $17^{\prime} \mathrm{N}$; $\left.30^{\circ} 53^{\prime} \mathrm{E}\right)$, Faculty of Agriculture, Fayoum University, Egypt, during the two growingseasons of 2016/2017 $(29.297672, \quad 30.922477)$ and 2017/2018 (29.297826, 30.922404). The experimental locations had history ofSclerotiumrolfsii infection (the experimental plot was planted with carrot for the two previous years). Soil samples were collected from the upper $30 \mathrm{~cm}$ layer and analyzed for some physical and chemical properties according to the methods described by Page et al.,(1982) as shown in Table 1. Another soil samples were collected before and after plowing the field to assess pathogen incidence as described by Punja et al., (1986).Tuber seeds of Jerusalem artichoke (Helianthus tuberosus L., cv. Baladi) were purchased from Agricultural Research Center, Qanater Station, Egypt 
TABLE 1. Some physical and chemical soil characters of the experimental farm

\begin{tabular}{|c|c|c|}
\hline Soil property & 2016/2017 season & $2017 / 2018$ season \\
\hline \multicolumn{3}{|l|}{ Particle size distribution } \\
\hline Sand $(\%)$ & 65.9 & 63.8 \\
\hline Silt $(\%)$ & 6.9 & 7.4 \\
\hline Clay $(\%)$ & 27.2 & 28.8 \\
\hline Soil texture & Sandy clay loam & Sandy clay loam \\
\hline pH (in soil paste) & 7.85 & 7.69 \\
\hline $\mathrm{ECe}\left(\mathrm{dSm}^{-1}\right)$ & 13.80 & 11.30 \\
\hline Organic matter $(\%)$ & 0.62 & 0.77 \\
\hline $\mathrm{CaCO}_{3}(\%)$ & 10.30 & 9.90 \\
\hline \multicolumn{3}{|l|}{ Soluble ions (meqL $\left.\mathrm{L}^{-1}\right)$} \\
\hline $\mathrm{CO}_{3}^{--}$ & ---- & ---- \\
\hline $\mathrm{HCO}_{3}^{-}$ & 5.13 & 4.05 \\
\hline $\mathrm{Cl}^{-}$ & 110.0 & 67.00 \\
\hline $\mathrm{SO}_{4}^{--}$ & 26.60 & 42.20 \\
\hline $\mathrm{Ca}^{++}$ & 38.50 & 24.50 \\
\hline $\mathrm{Mg}^{++}$ & 22.00 & 15.00 \\
\hline $\mathrm{Na}^{+}$ & 79.30 & 73.60 \\
\hline $\mathrm{K}^{+}$ & 2.02 & 2.19 \\
\hline Total N (\%) & 23.5 & 24.6 \\
\hline Extractable $\mathrm{P} \mathrm{NaHCO}_{3} \mathrm{pH}=8.5\left(\mathrm{mg} \mathrm{kg}^{-1}\right)$ & 13.10 & 12.10 \\
\hline Extractable $\mathrm{K} \mathrm{NH}_{4} \mathrm{OAC} \mathrm{pH}=7.0\left(\mathrm{mg} \mathrm{kg}^{-1}\right)$ & 301.00 & 311.00 \\
\hline \multicolumn{3}{|l|}{ DTPA Extractiblemicronutriments $\left(\mathrm{mg} \mathrm{kg}^{-1}\right)$} \\
\hline $\mathrm{Fe}$ & 0.4314 & 0.3388 \\
\hline $\mathrm{Mn}$ & 0.9466 & 1.5600 \\
\hline $\mathrm{Zn}$ & 0.2660 & 0.3350 \\
\hline $\mathrm{Cu}$ & 0.2766 & 0.2868 \\
\hline
\end{tabular}

Experimental design

Complete randomized block design (CRBD) was used with three replicates. Three different types of fermented organic fertilizers (FOM); farmyard (FYM), poultry (PLM) and pigeon (PGM) manure. Samples of organic fertilizers were collected from Animal and Poultry Production Unit of the 'Demo' Experimental Station during both seasons. Nitrogen, phosphorus, potassium and organic matter $(\%)$ were determined (Table 2) according to the procedures of Page et al. (1982). The FOM treatments at different rates (Table 3 ) were added each for 3 plots (each plot $=3.5$ length $\times 3.0$ width $=10.5 \mathrm{~m}^{2}$ ) containing 3 rows.

Control treatment plots were fertilized by chemical fertilizers only; $\mathrm{Ca}\left(\mathrm{H}_{2} \mathrm{PO}_{4}\right)_{2} 15.5 \% \mathrm{P}_{2} \mathrm{O}_{5}$, $\left(\mathrm{NH}_{4}\right)_{2} \mathrm{SO}_{4} 20.6 \% \mathrm{~N}$, and $\left(\mathrm{K}_{2} \mathrm{SO}_{4}\right) 48 \% \mathrm{~K}_{2} \mathrm{O}$, at the rates of 150,300 , and $150 \mathrm{kgfed}^{-1}$, respectively, as NPK sources. Phosphorus fertilizer was added with soil preparation for sowing and the amounts of nitrogen and potassium fertilizerswere equally divided and side dressed at 30 and 60 days after planting,while different organic manures treatments were applied to all plots except control treatment.All other recommended agricultural practices for Jerusalem artichoke production were adopted throughout growth seasons of 2016/2017 and 2017/2018 according to the bulletin of Egyptian Ministry of Agriculture (1020/2006).

Isolation of southern blight disease causal agent

The fungal pathogen was isolated from soil samples using dilution method on PDA medium with penicillin. Petri dishes were incubated at $25^{\circ} \mathrm{C}$ for $7 \mathrm{~d}$. All of the cultures were purified using the same isolation medium. Morphological identification was performed using colony characteristics, sclerotia under light microscopy at Plant Pathology labs, Faculty of Agriculture, Fayoum University, Egypt. Before and after plowing and fertilizing the soil, the inoculum density of the fungal pathogen was assessed by counting the sclerotia number per soil sample using wet-sieving procedure (Punja et al., 1986) 
TABLE 2. Analysis of the different organic fertilizers

\begin{tabular}{lcccccc}
\hline \multirow{2}{*}{ Organic manure } & \multicolumn{3}{c}{$\mathbf{2 0 1 6 / 2 0 1 7}$} & \multicolumn{3}{c}{$\mathbf{2 0 1 7 / 2 0 1 8}$} \\
\cline { 2 - 7 } & FYM & PLM & PGM & FYM & PLM & PGM \\
\hline $\mathrm{N}(\%)$ & 0.112 & 0.393 & 0.403 & 0.128 & 0.430 & 0.440 \\
$\mathrm{P}_{2} \mathrm{O}_{5}(\%)$ & 0.180 & 0.188 & 0.053 & 0.168 & 0.199 & 0.059 \\
$\mathrm{~K}_{2} \mathrm{O}(\%)$ & 0.082 & 0.456 & 0.350 & 0.086 & 0.490 & 0.398 \\
$\mathrm{O} . \mathrm{M}(\%)$ & 24.2 & 21.2 & 42.7 & 25.8 & 21.6 & 48.7
\end{tabular}

TABLE 3.The applied fertilizer organic fertilizers treatments

\begin{tabular}{cll}
\hline Treatment & Rates & Quantity of Organic fertilizers \\
\hline $\mathrm{T}_{0}$ & Control & No any of FOM was added \\
$\mathrm{T}_{1}$ & $\% 100 \mathrm{FYM}$ & $42 \mathrm{~kg}$ of farmyard manure only \\
$\mathrm{T}_{2}$ & $\% 100 \mathrm{PLM}$ & $42 \mathrm{~kg}$ of poultry manure only \\
$\mathrm{T}_{3}$ & $\% 100 \mathrm{PGM}$ & $42 \mathrm{~kg}$ of pigeon manure only \\
$\mathrm{T}_{4}$ & $75 \% \mathrm{FYM}+25 \% \mathrm{PLM}$ & $31.5 \mathrm{~kg}$ of farmyard manure $+10.5 \mathrm{~kg}$ poultry manure \\
$\mathrm{T}_{5}$ & $75 \% \mathrm{FYM}+25 \% \mathrm{PGM}$ & $31.5 \mathrm{~kg}$ of farmyard manure $+10.5 \mathrm{~kg}$ pigeon manure \\
$\mathrm{T}_{6}$ & $75 \% \mathrm{PLM}+25 \% \mathrm{FYM}$ & $31.5 \mathrm{~kg}$ of poultry manure $+10.5 \mathrm{~kg}$ farmyard manure \\
$\mathrm{T}_{7}$ & $75 \% \mathrm{PLM}+25 \% \mathrm{PGM}$ & $31.5 \mathrm{~kg}$ of poultry manure $+10.5 \mathrm{~kg}$ pigeon manure \\
$\mathrm{T}_{8}$ & $75 \% \mathrm{PGM}+25 \% \mathrm{FYM}$ & $31.5 \mathrm{~kg}$ of pigeon manure $+10.5 \mathrm{~kg}$ farmyard manure \\
$\mathrm{T}_{9}$ & $75 \% \mathrm{PGM}+25 \% \mathrm{PLM}$ & $31.5 \mathrm{~kg}$ of pigeon manure $+10.5 \mathrm{~kg}$ poultry manure \\
\hline
\end{tabular}

\section{Disease assessment}

Twenty random plants/plot were assessed for disease incidence each $10-30$ days after post emergence of seedlings(14 days after sowing; DAS) (Junsopa et al., 2016 with modifications). Southern stem rot disease incidence was calculated using the following formula according to Cooke (2006).

Whereas disease severity was scored using the scale $0-5$ scale/plant(Sennoiet al. 2010), where; 0 $=$ healthy plants, $1=$ lesions without wilting, $2=$ 1-2 wilted leaves, $3=$ more than 2 wilted leaves, $4=$ damped off plant, and $5=$ dead plant. These disease score dates were converted to severity index as described by Junsopaet al.(2016)

Data of disease incidence were transformed to the area under disease progress curve (AUDPC) as follows (Davis et al., 1996)

$$
A U D P C=\sum_{i=1}^{n}\left[\frac{X_{i}+X_{i-1}}{2}\right] \frac{1}{t_{i}-t_{i-1}}
$$

Where: $\boldsymbol{i}$ is the number of days in which the observations were made, $\boldsymbol{n}$ is the last days in which observations were done, $\boldsymbol{X}_{\boldsymbol{i}}$ is the disease incidence in days $\boldsymbol{i}$, and $\boldsymbol{t} i$ is the time assessing the disease incidence.

\section{Vegetative growth characters}

A random sample of three plants from each experimental plot was taken at flowering initiation stage (120 DAS) to record plant height $(\mathrm{cm})$, number of lateral branches plant ${ }^{-1}$, leaffresh and dry weights,stem fresh and dry weights $(\mathrm{g})$ and leaf area plant ${ }^{-1}$. All of these characters were carried out according to procedures of A.O.A.C. (1992).

\section{Leaves chemical constituents}

Random samples from the upper fourth leaf were collected and washedby distilled water to estimatethe chlorophyll index using SPAD 502 plus chlorophyll meter.Thereafter, samples wereoven dried at $70^{\circ} \mathrm{C}$ to determine the contents of nitrogen, phosphorus and potassium according to the methods described in A.O.A.C. (1992). 


\section{Tuber quality}

Inulin content was determined in tubers according to the methods of Winton and Winton (1985).Total phenolic compounds (TPCs) were extracted from a fresh sample $(1.0 \mathrm{~g})$ using the method of Taga et al.(1984).Total nitrogen, phosphorus and potassium were determined by Pageet al. (1982). Total metal concentrations were determined by the inductively coupled plasmaoptical emission spectrometry (ICP-OES, PerkinElmer OPTIMA-2100 DV, Norwalk, CT).

\section{Yield and its components}

At harvest time (270 DAS), the average tuber fresh and dry weights $(\mathrm{g})$, total yield $\left(\mathrm{kgfed}^{-1}\right)$, and percentage of tuber dry weight (calculated by drying $100 \mathrm{~g}$ of fresh tubers in an electricoven at $70^{\circ} \mathrm{C}$ till a constant weight).

\section{Statistical analysis}

The analysis of variance (ANOVA) and LSD were calculated by using GENSTAT statistical package, version 9.2 (GENSTAT, 2007).

\section{Results and Discussion}

\section{Vegetative growth characters}

Plant height and number of lateral shoots

The highest values of plant height (101.33 and $95.22 \mathrm{~cm})$ were recorded for $\mathrm{T}_{8}(75 \% \mathrm{PGM}+25 \%$ FYM) treatment followed by $\mathrm{T}_{6}(75 \%$ PLM $+25 \%$ FYM) treatment.However the lowest value $(73.00 \mathrm{~cm})$ was recorded with $\mathrm{T}_{1}(100 \% \mathrm{FYM})$ treatment. The magnitudes of increasing in plant height were 24.46 and $19.61 \%$ in $2016 / 2017$ season as compared with the control treatment.On the other side, in 2017/2018 season, the highest values (118.56 and $114.78 \mathrm{~cm})$ were recorded withT 2 (100\% PLM) treatment followed by $\mathrm{T}_{5}(75 \% \mathrm{FYM}+25 \%$ PGM $)$ treatment as the lowest value was obtained with $\mathrm{T}_{0}$ (the control), with the increasing rates of 22.12 and $19.56 \%$, respectively.

With respect to thenumber of lateral shoots, the highest values (22.00 and 18.89) were recorded with $\mathrm{T}_{8}$ treatment followed by $\mathrm{T}_{6}$ treatment (Table 4). On the other hand, the lowest value (6.33) was showed with $\mathrm{T}_{9}(75 \% \mathrm{PGM}+25 \%$ PLM $)$ treatment. The amountsof increase were 71.23 and $57.09 \%$, respectively compared to the lowest value of the first season.In the second season, the highest number of lateral shoots wasfound with $\mathrm{T}_{2}$ followed by $\mathrm{T}_{5}$ treatment, but the lowest one was obtained with the control $\left(\mathrm{T}_{0}\right)$, the increasing rate was 54.13 and $50.28 \%$, respectively, as compared to control. These resultsare inline with the findings of Nelson et al. (1970), as organic manures play a significant role in plant nutrition.
Organic manures especially farmyard manure could raise the concentrations of many nutrients and the soil enhance the nutritional value and nutrient balance of plants Graham et al., (2000). Organic acids such as citric, malic, oxalic and phenol that form $\mathrm{Fe}$ complexes are released when organic matter of organic manures decomposes Dauda et al. (2008). Poultry manure is relatively resistant to microbial degradation, establishing and maintaining optimum soil physical conditions that are important for plant growth. It is good source of nitrogen for sustainable crop production Massriand Labban (2014).

Number of leaves and leaf area

It is clear that $\mathrm{T}_{8}(75 \% \mathrm{PGM}+25 \% \mathrm{FYM})$ followed by $\mathrm{T}_{6}(75 \%$ PLM $+25 \% \mathrm{FYM})$ treatments showed the highest values for no. of leaves and leaf area of Jerusalem artichokeduring 2016/2017 season (Table 4).On the other hand, in 2017/2018 season, the highest values were recorded with $\mathrm{T}_{5}(75 \% \mathrm{FYM}+$ $25 \%$ PGM) followed by $\mathrm{T}_{7}(75 \%$ PLM $+25 \%$ PGM) treatments for no. of leaves and with $\mathrm{T}_{7}$ $(75 \% \mathrm{PLM}+25 \% \mathrm{PGM})$ followed by $\mathrm{T}_{2}(100 \%$ PLM) treatments for leaf area. Increase of 69.22 and $66.72 \%$ for no. of leaves and $56.34 \%$ and $56.15 \%$ for leaf area were obtained from these respective treatments.

These results are in harmony with those obtained by Ragab et al. (2008). These findings may be attributed to the main role of organic fertilizers which they are a source of slow release macronutrients and improved the physical, chemical and biological properties of the soil (Anwar et al., 2011).

Poultry manure is essential for establishing and maintaining the optimum physical condition for plant growth (Enujeke et al., 2013). It is the effective source of nitrogen for sustainable crop production (Ewulo et al., 2008).

\section{Leaf and stem fresh and dry weight}

Plants that received 75\% PGM + 25\% FYM (T8) had the highest values during the first season, and $100 \%$ PLM (T2) in the second season showed also the highest values of leaf and stem fresh and dry weights (Table 4). Similar results were obtained by El-Sharkawy (2007) on taro and Eifediyi et al., (2010) on cucumber. The application of pigeon manure and farm yard manure increased the fresh weigh and dry matter of leaves and stem. This increase could be attributed to the increase in the nutrient availability and their uptake by plants (Eifediyiet al., 2010; Hoseini et al., 2013). 


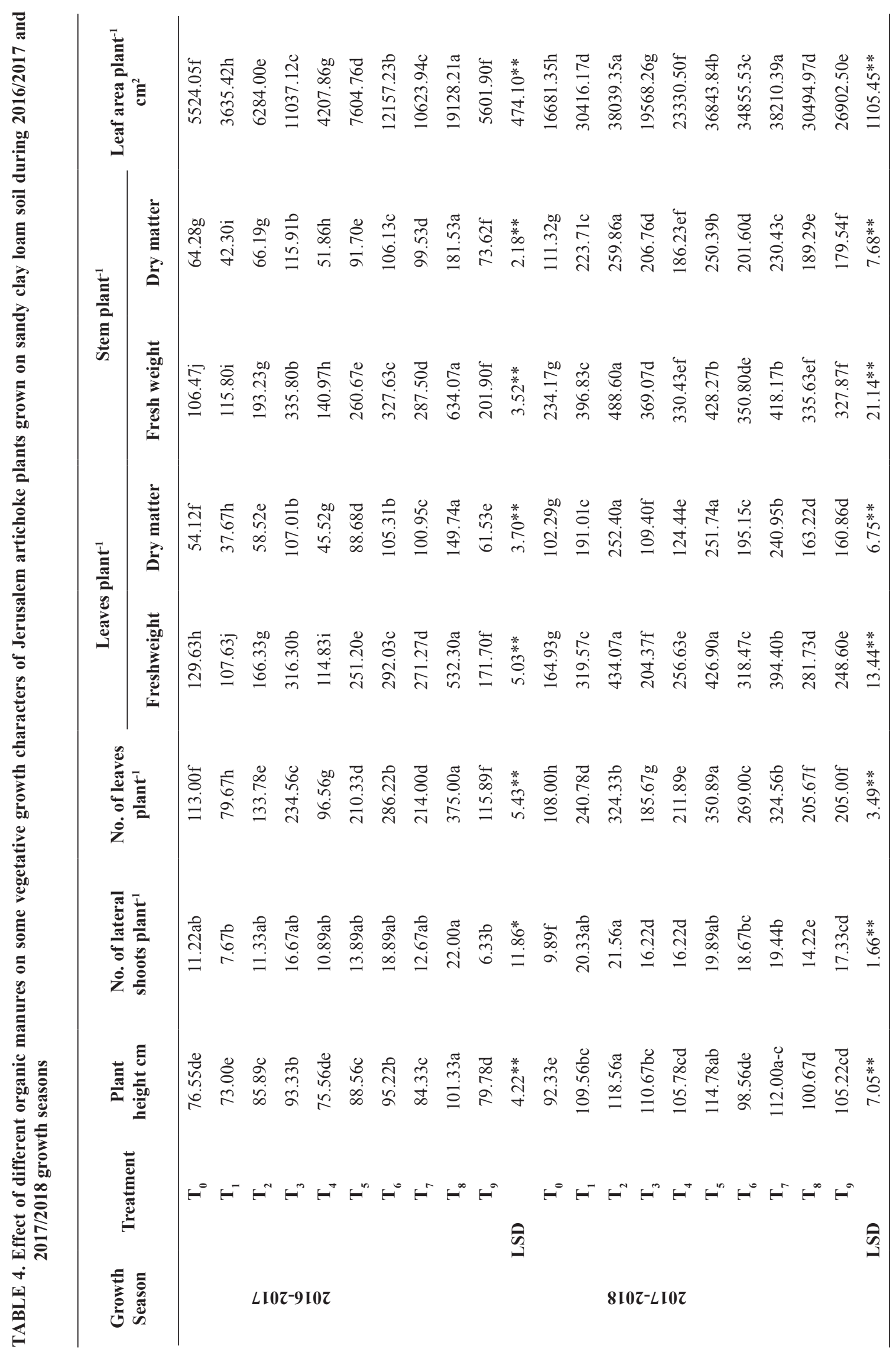

Egypt. J. Soil Sci., 58, No. 4 (2018) 
Chemical constituents

\section{Leaves}

Relative chlorophyll content

The application of T4(75\% FYM $+25 \%$ PGM) followed by T3 treatments (75\% FYM $+25 \%$ PLM) recorded the highest chlorophyll values (39.16 and 38.60 , respectively) of Jerusalem artichoke in 2016/2017, while
$75 \%$ FYM $+25 \%$ PLM (T3) followed by T4 treatments $(75 \% \mathrm{FYM}+25 \% \mathrm{PGM})$ showed the highest chlorophyll values (34.80 and 34.16 , respectively) in 2017/2018. However, the lowest chlorophyll values (35.01 and 31.88) were obtained with applying $75 \% \mathrm{PGM}+25 \%$ PLM (T9) in 2016/2017 and 2017/2018growth seasons, respectively (Figure 1).

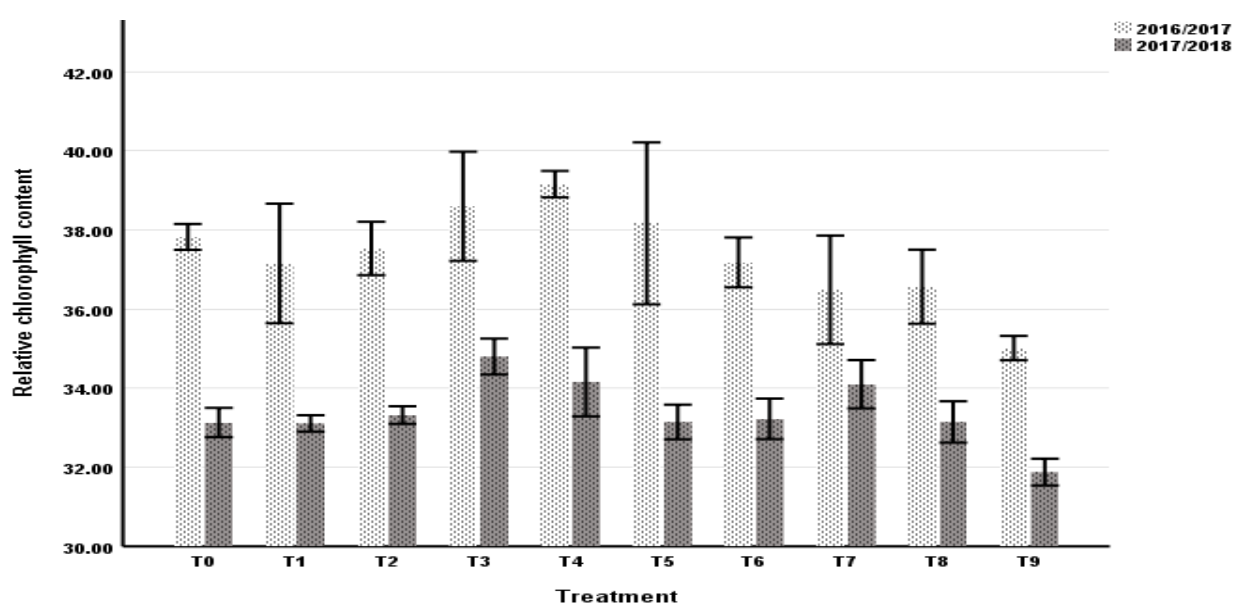

Fig.1. Effect of some different organic manures and their combinations on leaves chlorophyll index.

The present results coincide with those reported by Karanatsidis and Berova (2009). They may be attributed to the increased photosynthesis and the stabilizing effect of the organic fertilizer upon the chlorophyll-protein complex. In addition to pigeon manure had the highest $\mathrm{N}$ content. Regarding the role of $\mathrm{N}$ in the vegetative growth, the high $\mathrm{N}$ content in pigeon manure would probably increase the no of leaves and leaf weight (Hoseiniet al., 2013).

Nitrogen, phosphorus and potassiumcontent of leaves

The chemical composition of Jerusalem artichoke leaves, i.e. nitrogen; phosphorus and potassium were influenced with applying the different organic manures and their combinations (Table 5). It is of great interest to notice that the highest values were found with $\mathrm{T} 7$ (75\%PLM $+25 \% \mathrm{PGM})$ treatment for the three studied nutrients (NPK)in both of seasons. There were no significant differences between the control and different organic manurecombination treatments $(\mathrm{P}=0.05)$ for $\mathrm{N}$ and highly significant differences for $\mathrm{P}$ in both season,respectively. While no significant and high significant differences for $\mathrm{K}$ in 2016/2017 and 2017/2018 growth seasons respectively.
These results agree with those the laboratory analysis results of the studied applied organic manureswhich showed that PLM had the highest $\mathrm{P}$ and $\mathrm{K}$, but PGM had the highest $\mathrm{N}$ content as it is shown in (Table 5).

The effect of the different organic manures and their applied levels might be due to their decomposition of micro-organisms through one or more mechanisms such as nitrogen fixation, production of organic acids, enhancing nutrients uptake, synthesis of vitamins, amino acids, auxins and gibberellins which stimulate the plant growth Haggag, et al. (2015).

Tubers

Total phenolic compounds and Inulin of tuber

The total phenolic compounds (TPCs) were significantly different $(p \leq 0.05)$ due to the effect organic manures and its combinations (Figure 2). The effect of different organic manures and its combinations on total phenolic compounds (TPCs) of tubers is presented in Fig 2.The highest values of those compounds were found with T2treatment and were 19.60 and 20.86 in both seasons respectively, followed by T4 (17.06) in the first season and by T5 (18.42) in the second season. In contrary the lowest values (12.60 and 13.50) were recorded with T9 treatment in both of seasons, respectively. 


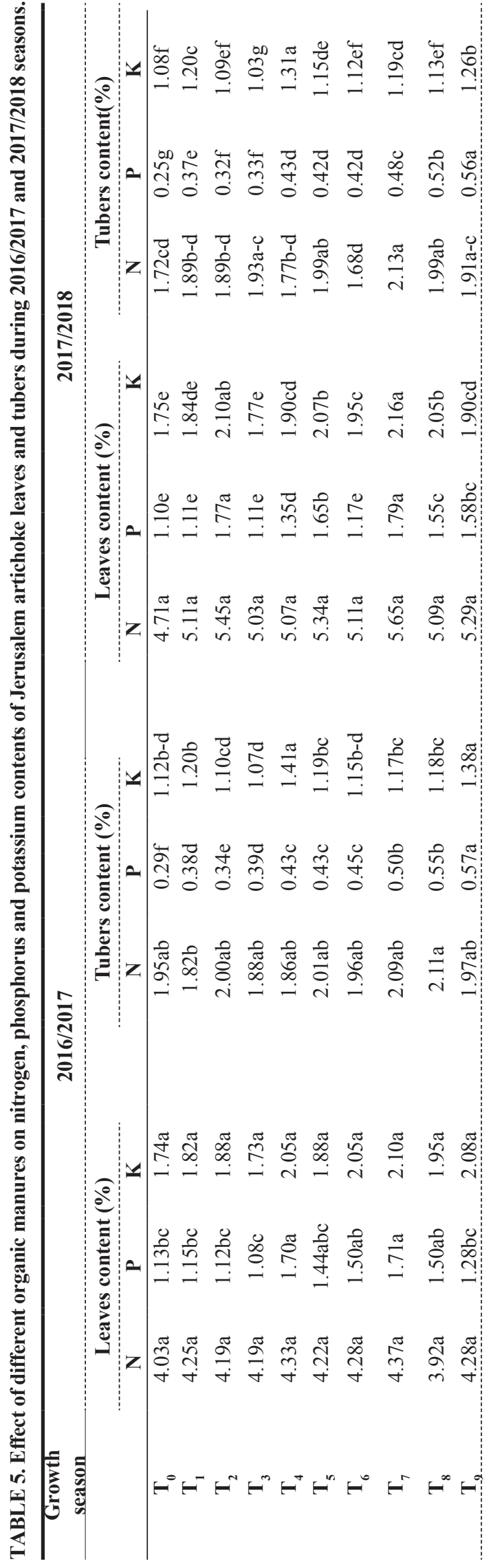

Egypt. J. Soil Sci., 58, No. 4 (2018)
These results are in harmony with those reported by Franco et al.(2002).The total phenolic compounds(TPCs)are synthesized through a secondary metabolism cycle and it could produce some plant hormones.

The effect of different organic manures and their combinations on inulin percent of Jerusalem artichoke tubers was found in (Figure 3). The highest values (12.39 and $11.67 \%$, respectively) followed by (12.21 and $11.52 \%$, respectively) were presented with $\mathrm{T}_{6}$ and $\mathrm{T}_{7}$ treatments in the first season and $\mathrm{T}_{4}$ and $\mathrm{T}_{9}$ treatments in the second season. On the other hand, the lowest values (10.38 and 10.49\%) were showed with $\mathrm{T}_{0}$ treatment (control) in both of seasons. These results are agreed with those reported El-Sirafyet al. (2008), and these results might be due to organic manures applying improved the mineral status of JA plants Kolota and Osinska (2006).

Nitrogen, potassium and phosphorus contents of tubers

The chemical composition of Jerusalem artichoke tubers, i.e. nitrogen, phosphorus and potassium were affected by using organic manures and their combinations as shown in Table 5. The highest values (2.11 and 2.09\%) for nitrogen, (0.57 and $0.55 \%$ ) for phosphorus and (1.41 and $1.38 \%$ ) for potassium were found with $\mathrm{T}_{8}$ and $\mathrm{T}_{7}$ treatments for nitrogen, $\mathrm{T}_{9}$ and $\mathrm{T}_{8}$ treatments for phosphorus and $\mathrm{T}_{4}$ and $\mathrm{T}_{9}$ treatments for potassium in 2016/2017 growth season.On the other hand the highest values (2.13 and $1.99 \%)$ for nitrogen, (0.56 and 0.52$)$ for phosphorus and (1.31 and 1.26) for potassium was found with $T_{7}$ and $T_{5}$ for nitrogen, $T_{9}$ and $T_{8}$ for phosphorus and $\mathrm{T}_{4}$ and $\mathrm{T}_{9}$ treatments for potassium in 2017/2018 growth season. These results agreed with those reported by Haggag et al. (2015), however the effect of the different organic manures and their combinations might be due to their decomposition micro-organisms through one or more mechanisms such as nitrogen fixation, production of organic acids, enhancing nutrients uptake, synthesis of vitamins, amino acids, auxins and gibberellins which stimulate the plant growth Haggag et al. (2015).

Cadmium, lead and nickel content of tubers

The influence of fertilizers organic manure combinations on some heavy metals $i$.e c cadmium $(\mathrm{Cd})$; lead $(\mathrm{Pb})$ and nickel $(\mathrm{Ni})$ in tuber Jerusalem artichoke showed in Figures ( $7 ; 8$ \& 9), the lowest values $(0.05$ and 0.09 for $\mathrm{Cd})$ were recorded with applying $75 \% \mathrm{PLM}+25 \% \mathrm{PGM}\left(\mathrm{T}_{7}\right) ;(1.40$ and 1.27 for $\mathrm{Pb}$ ) with $100 \% \mathrm{PGM}\left(\mathrm{T}_{3}\right)$ and $75 \% \mathrm{FYM}+25 \%$ PLM $\left(\mathrm{T}_{4}\right)$ and (2.59 and 2.57 for Ni) with applying $75 \%$ FYM $+25 \%$ PLM $\left(\mathrm{T}_{9}\right)$ in $2016 / 2017$ and 2017/2018, respectively. 


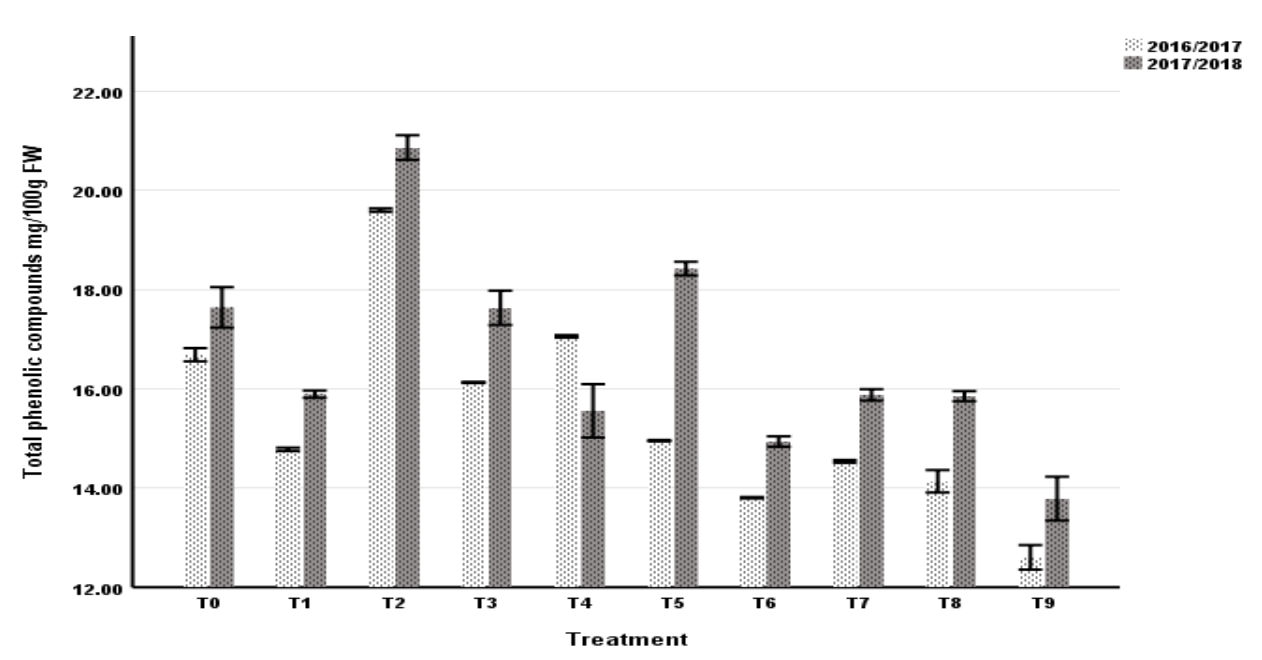

Fig. 2. Effect of some different organic manures and their combinations on total phenolic compounds of Jerusalem artichoke tubers.

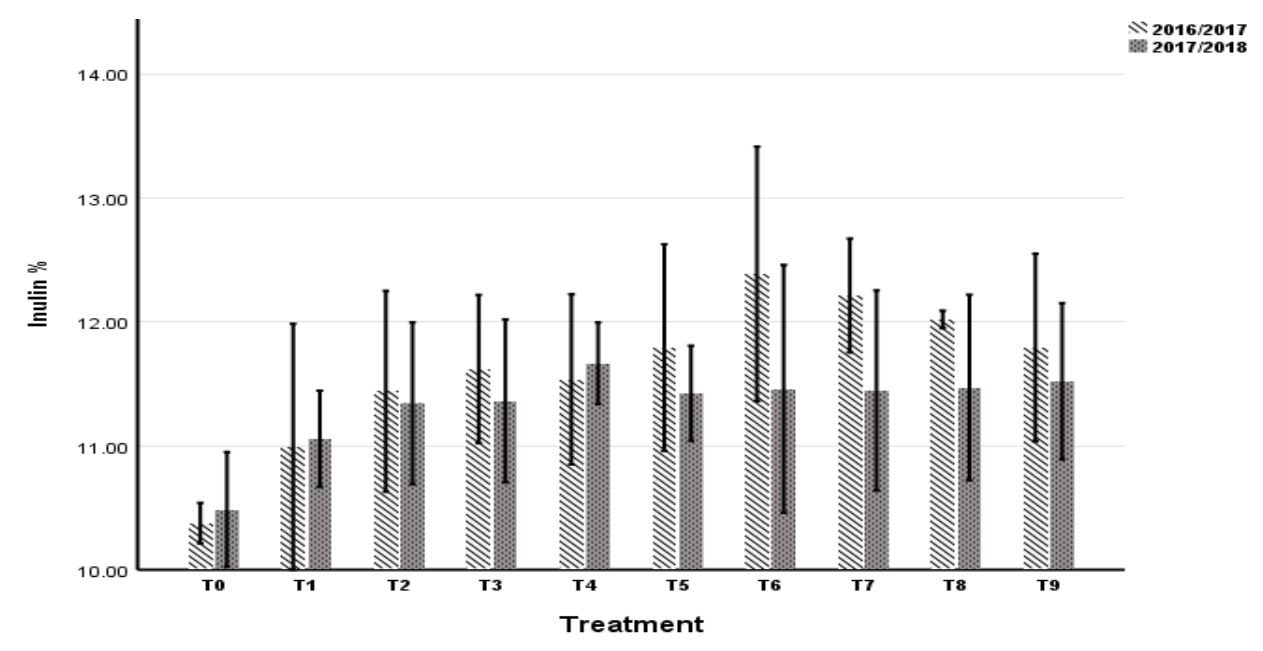

Fig. 3. Effect of some different organic manures and their combinations on inulin \% of Jerusalem artichoke tubers.

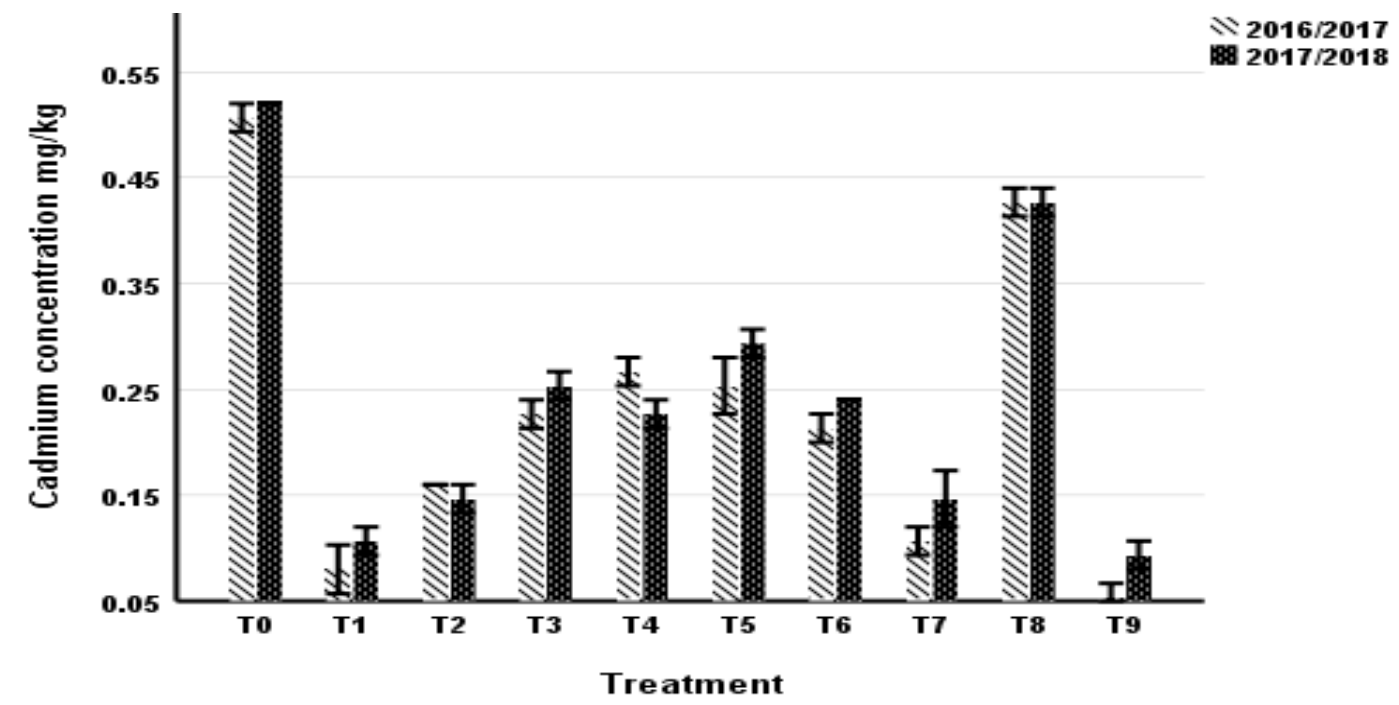

Fig.4. Effect of some different organic manures and their combinations on cadmium content of Jerusalem artichoke tubers Egypt. J. Soil Sci., 58, No. 4 (2018) 


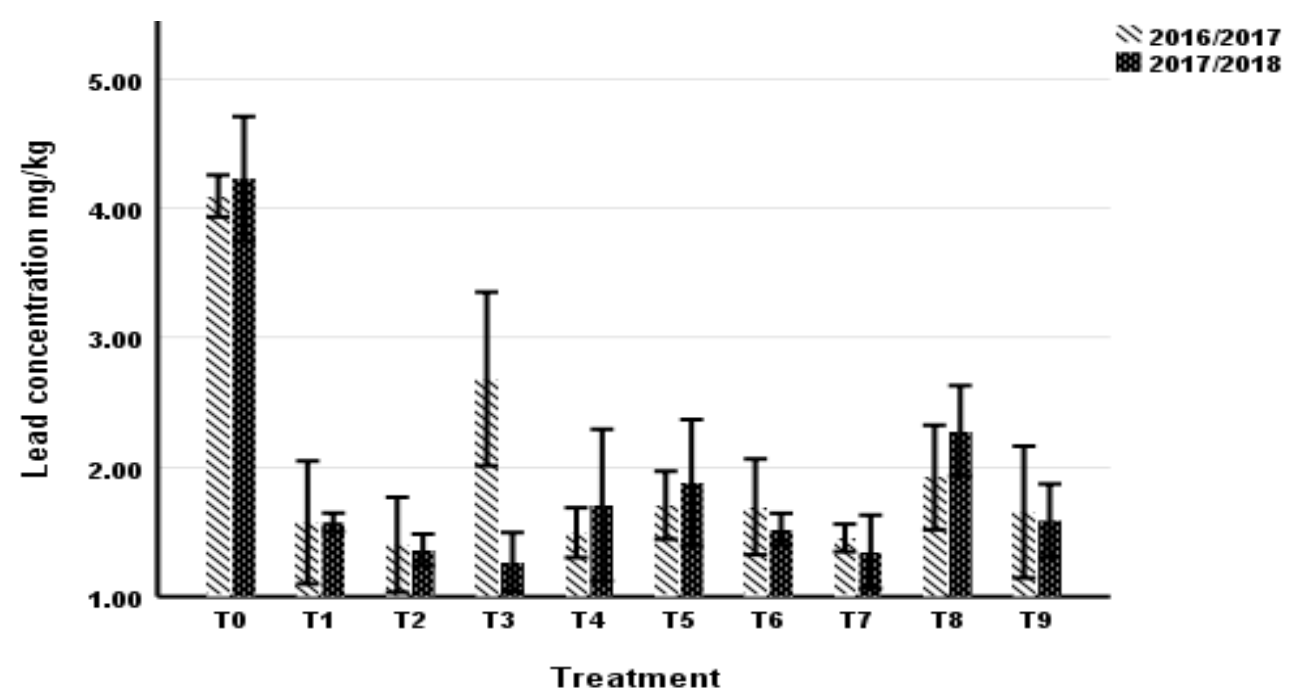

Fig. 5. Effect of some different organic manures and their combinations on lead content of Jerusalem artichoke tubers

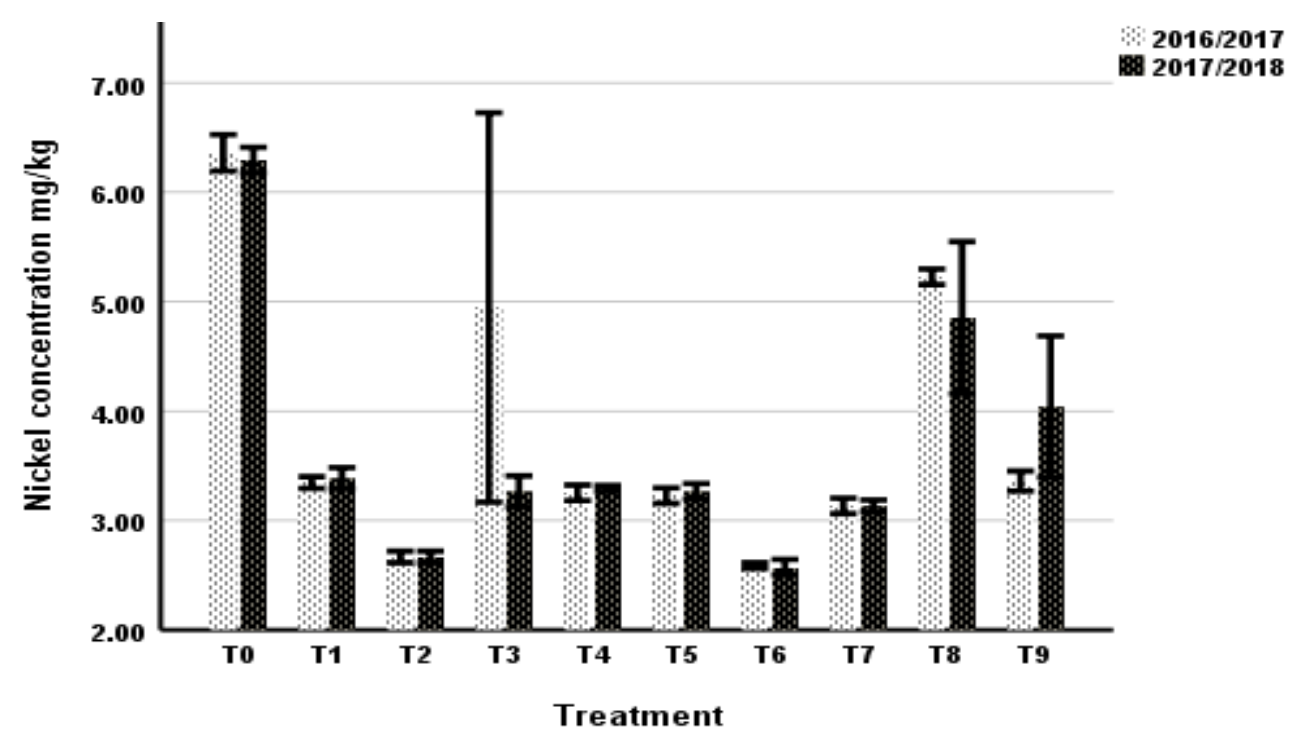

Fig. 6. Effect of some different organic manures and their combinations on nickel content of Jerusalem artichoke tuber

The ANOVA results indicated showed that the $\mathrm{Cd} ; \mathrm{Pb}$ and $\mathrm{Ni}$ were significantly affected by applying all organic manures combinations treatments as a comparing with control at $1 \%$ probability level.

\section{Yield and its components \\ Tuber fresh and dry weight}

Table 6 shows the effect of different organic manures and its combinations on tuber fresh and dry weights and \% of dry matter. The highest values were recorded with $T_{2}$ followed by $\mathrm{T}_{4}$ treatments for tuber fresh weight (1395.33 and $1328.23 \mathrm{~g}$, respectively), dry weight (347.13 and
$338.40 \mathrm{~g}$, respectively) and tuber dry matter \% (26.32 and $24.31 \%$, respectively) in 2016/2017 growth season.However, data in 2017/2018 season the respective highest values $(1050.00$ and $1026.00 \mathrm{~g}$, respectively) were showed with plants applied with 100\% PGM $\left(\mathrm{T}_{3}\right)$ followed by $75 \%$ PLM $+25 \%$ PGM $\left(\mathrm{T}_{7}\right)$ for tuber fresh weigh, while for tuber dry weight, $\mathrm{T}_{7}$ treatment had the highest value (314.43 g) followed by $\mathrm{T}_{3}$ (310.86 g).For dry matter percentage, the respective highest values (33.27 and $31.89 \%$, respectively) wererecorded with $\mathrm{T}_{6}$ followed by $\mathrm{T}_{8}$. The treatments had not significantly affect 
the tuber fresh weight in both seasons, therewere significantlydifferences from the control at $(\mathrm{P} \leq 0.01)$ for tuber dry weight. The dry matter percentage significantly differed at the first season but did not differ at the second season.

The obtained results are in an agreement with those reported by Raramurthy and Shivashankar (1996), who stated that organic manure improved the plant height, dry matter production at different stages of crop growth and yield attributing characters of corn. In addition, the application of FYM increased the dry weight and yield due to the nutrient availability and its uptake by the plants (Eifediyiet al., 2010).

\section{Total yield and its components}

The plants that were fertilized with $75 \%$ $\mathrm{PLM}+25 \% \mathrm{PGM}\left(\mathrm{T}_{7}\right)$ recorded the highest total yield values of $\left(20423.20\right.$ and $9730.56 \mathrm{~kg} \mathrm{fed}^{-}$ ${ }^{1}$ ) in 2016/2017 and 2017/2018, respectively, followed by $\mathrm{T}_{4}(75 \% \mathrm{FYM}+25 \%$ PLM) in the first season and $\mathrm{T}_{2}(100 \%$ PLM) in the second season (Table 6). The lowest total yield values were obtained with $\mathrm{T}_{5}$ (75\% FYM $+25 \%$ PGM) in both seasons; thereby, the increasing rates were 69.90 and $49.60 \%$ in 2016/2017 and 2017/2018 growth seasons, respectively. The application of
$\mathrm{T}_{7}$ treatment in both growth seasons significantly increased the total yield $(\mathrm{P} \leq 0.001)$ over those of the control $\left(\mathrm{T}_{0}\right)$.

In this respect, similar findings were also found by Ahmed and Elzaawely (2010) and Ahmed et al. (2013). The increase in total yield may be attributed to the high contents of N; P and $\mathrm{K}$ in poultry and pigeon manures that encourage the adsorption of these nutrients by Jerusalem artichoke plants to go forward and accelerate the photosynthetic rate Ahmed and Elzaawely, (2010).

\section{Disease assessment}

Pathogen determination and its inoculum density

The pathogen isolated was identified as Sclerotiumrolfsii with typical morphological characteristics as described by Cúndomet al. (2013). The inoculum density of Sclerotiumrolfsii was expressed as number of sclerotia $/ 300 \mathrm{~cm}^{3}$ of soil samples (Figure 7). The inoculum density average was about 16.5 and 17.5 sclerotia in soil sample before plowing soil which decreased by 22.7 and $22.1 \%$ to be about 13 and 13.5 sclerotia/ soil samples in 2016/2017 and 2017/2018 respectively

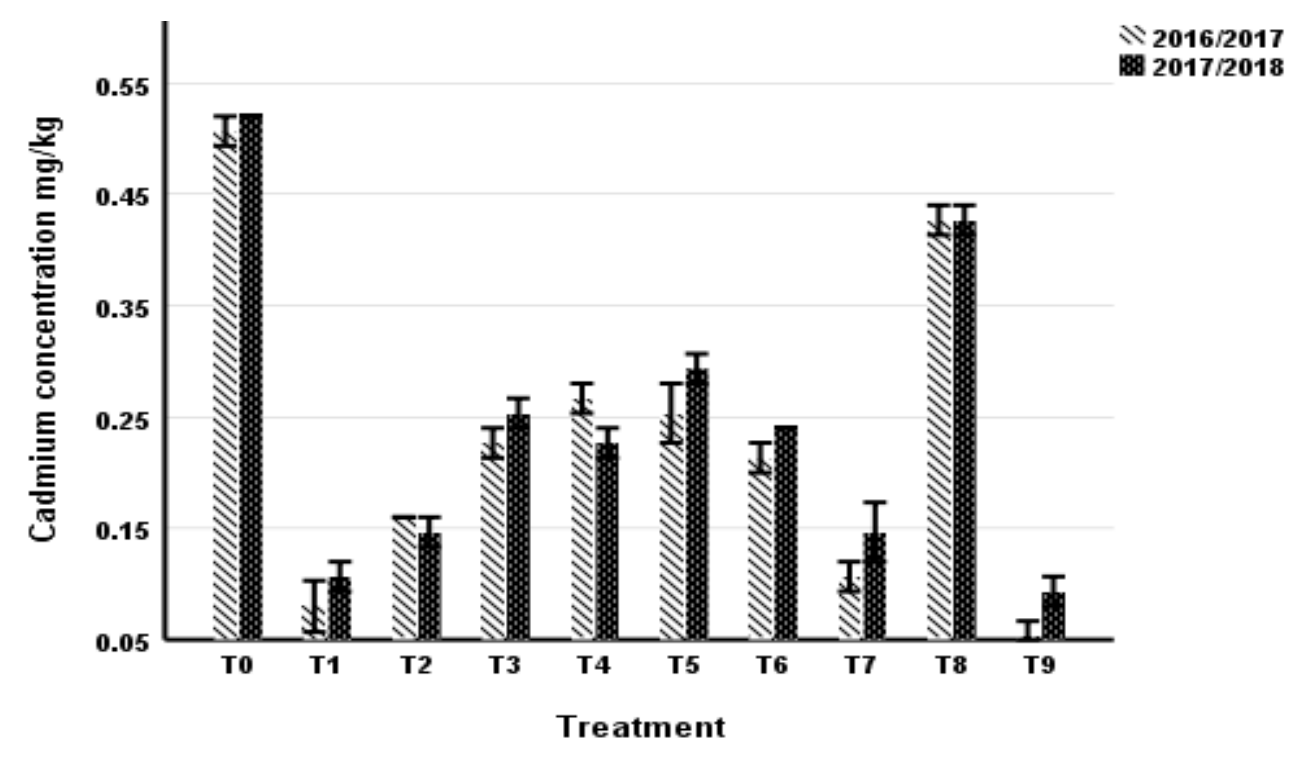

Fig. 7. The inoculum density of Sclerotiumrolfsii was expressed as number of sclerotia $/ 300 \mathrm{~cm}^{3}$ of soil samples before and after plowing \&adding fertilization regime 


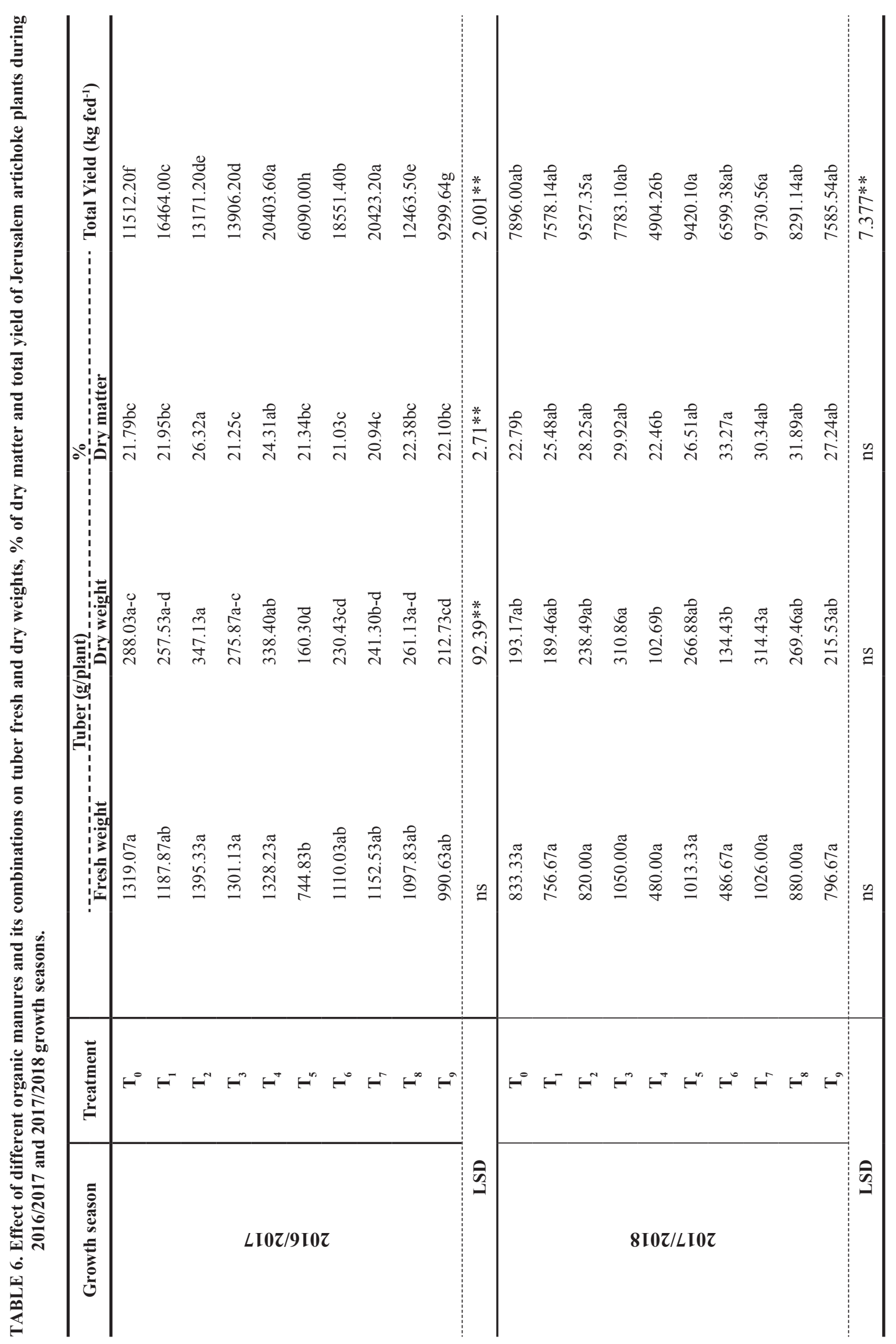

Egypt. J. Soil Sci., 58, No. 4 (2018) 


\section{Disease assessment}

All the studied fertilization regime of FOM had significantly reduced the percent of southern blight disease incidence as shown in (Figure 8) with reference to control treatment $\left(\mathrm{T}_{0}\right)$ with exception to $\mathrm{T}_{6}, \mathrm{~T}_{3}$, and $\mathrm{T}_{4}$. The treatments $\mathrm{T}_{2}$ followed by $\mathrm{T}_{1}$ andT $\mathrm{T}_{5}$ had the highest high DI reduction; 45.3, 38.5 , and $38.5 \%$ respectively. All the treatments had significantly decreased the SI with reference to the control one. Meanwhile, the severity index was positively decreased in $\mathrm{T}_{7}$ during the two years of study (Figure 9). Generally, negativetrendbetween number lateral shoots per plant and its severity index was observed, where the increase number of lateral shoots the decrement of disease severity by escaping from infection or producing new shoots to compensate the infected ones, which is combined with the plant height as; $\mathrm{T}_{7}$ and $\mathrm{T}_{9}$ corresponding the tothe type of FOM and their percentages used. The highest significant decrement of the treatment $\mathrm{T}_{7}$ might be to the heist $\%$ of potassium in leaves (as indicator to vegetative growth) which decreasing the fungal ability penetration or disease progress into the plant tissues.

$\mathrm{T}_{7}$ had the lowest significantly area under disease progress curve which might be an evidence on its efficacy in suppressing the disease progress (Figure 10). $\mathrm{T}_{2}(100 \% \mathrm{FYM})$ had the highest significant reduction of the DI percentage only. While, The best treatment of nitrogen, phosphorus and potassium contents of leaves, tuber fresh and dry weights, dry matter and total yield was obtained from using $\mathrm{T}_{7}(75 \%$ PLM $+25 \%$ PGM) treatment. The same treatment $\mathrm{T}_{7}$ had the highest significant decreasing rate of DI and AUDPC.

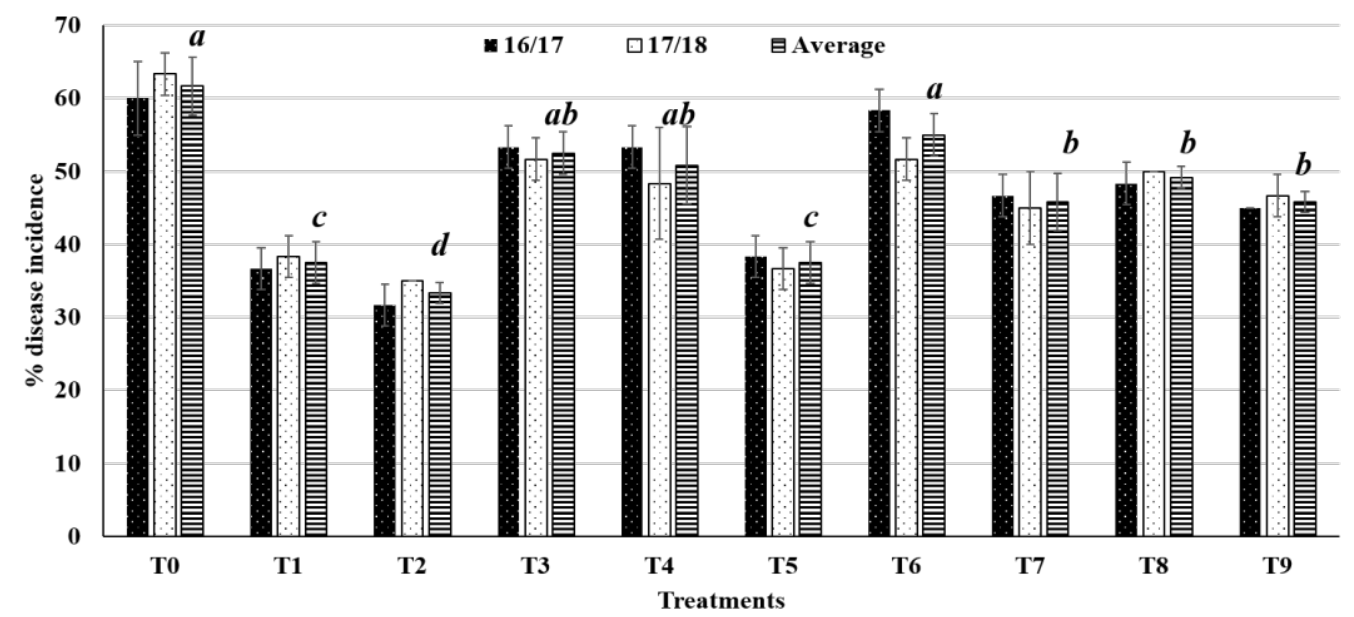

Fig.8. Percentage of southern blight disease incidence in Jerusalem artichoke with three different fermented organic manures fertilizationsand their combinations during the twoseasons.

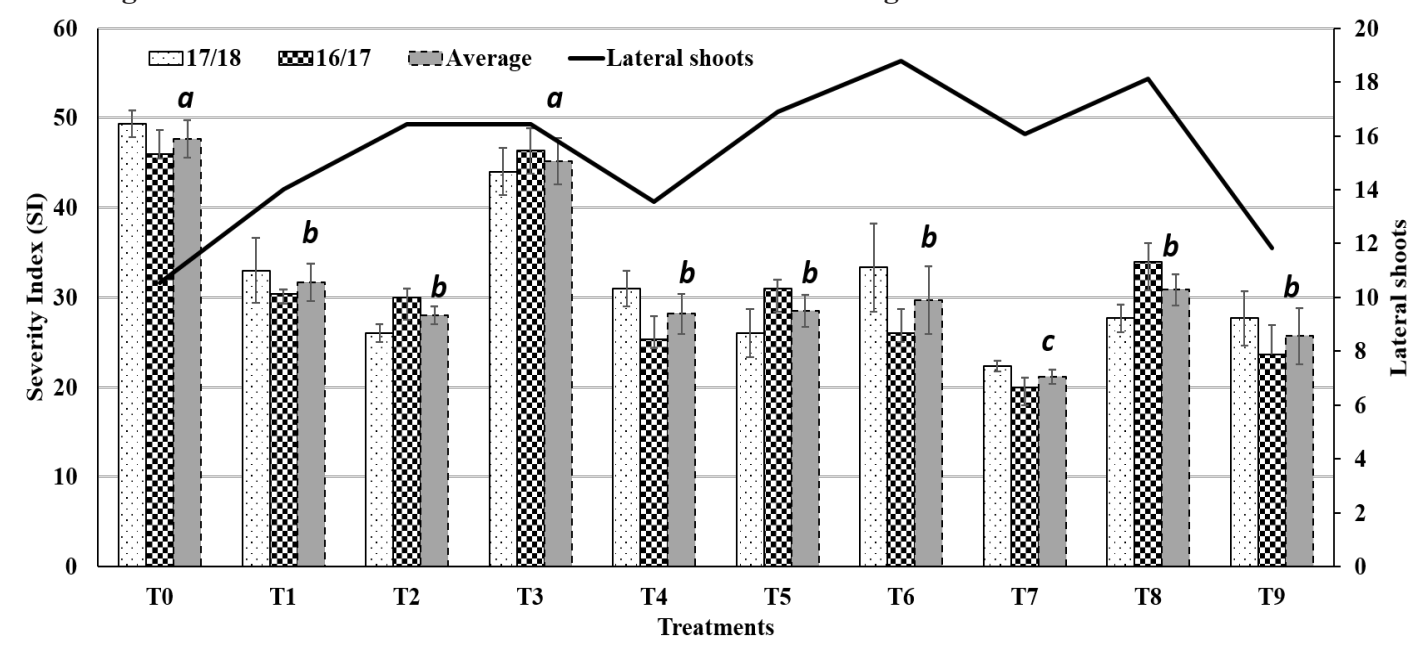

Fig. 9. Southern blight disease severity index (SI) in Jerusalem artichoke and number of plant lateral shoots with three different fermented organic manures fertilizations and their combinations during the two seasons 


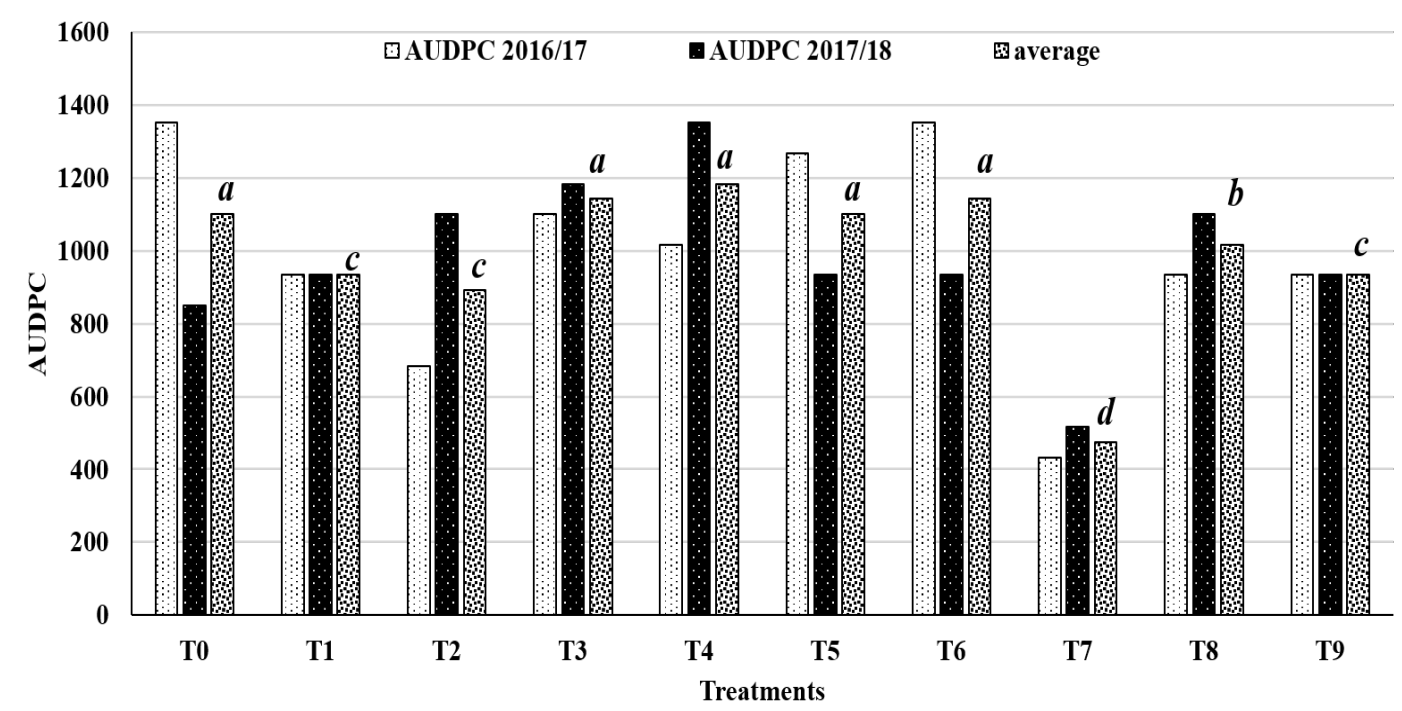

Fig. 10. AUDPC means for Southern blight disease incidence in Jerusalem with three different fermented organic manures fertilizations and their combinations during the two seasons

\section{Conclusion}

From the previous results of this investigation, it could be concluded that all different organic fertilizers and their combinations affected the studied characters. With regard to the highest values for plant height, number of lateral shoots, leaves and stem fresh and dry weights plant ${ }^{-1}$ were recorded with applying $\mathrm{T}_{8}(75 \% \mathrm{PGM}+25 \%$ FYM $)$ and $\mathrm{T}_{2}(100 \%$ PLM $)$ in $2016 / 2017$ and 2017/2018, respectively. On the other hand, $\mathrm{T}_{7}(75 \% \mathrm{PLM}+25 \% \mathrm{PGM})$ was the best treatment for nitrogen, phosphorus, potassium, nickel content of leaves and total yield, while $\mathrm{T}_{9}(75 \%$ PGM $+25 \%$ PLM) was the better for phosphorus, $\mathrm{T}_{4}(75 \% \mathrm{FYM}+25 \%$ PLM)for potassium content of tubers and $T_{2}$ was the better for total phenolic compounds of tubers in the first and second seasons.But, the results were not similar for other some characters; however the greatest values were showed with using $\mathrm{T}_{8}$ and $\mathrm{T}_{5}(75 \%$ FYM $+25 \%$ PGM)for number of leaves plant ${ }^{-1}$; $\mathrm{T}_{6}(75 \% \mathrm{PLM}+25 \% \mathrm{FYM})$ and $\mathrm{T}_{4}(75 \% \mathrm{FYM}+25 \%$ PLM)for inulin content; $\mathrm{T}_{4}$ and $\mathrm{T}_{3}(100 \% \mathrm{PGM})$ for SPAD reading; $\mathrm{T}_{8}$ and $\mathrm{T}_{7}$ for nitrogen content of tubers; $\mathrm{T}_{3}$ and $\mathrm{T}_{4}$ for the lowest level of lead content of tubers in 2016/2017 and 2017/2018, respectively.

\section{References}

Ahmed A. E., Mukhtar, N. O., Babiker, H. M. and Adam, A. I. (2013) Effect of farm yard manure and chicken manure on growth and yield of pigeon pea

Egypt. J. Soil Sci., 58, No. 4 (2018) and their residual effect on a subsequent sorghum crop. Sudan J. Agric. Res: 22, 23-70.

Ahmed, M.E.and Elzaawely, A. (2010) Growth and yield of cowpea plants in response to organic fertilization. Australian J. of Basic and Applied Sci. 4 (8), 3244-3249.

Anwar, R.S.M., Ramadan, M.M.A. and Easily, I.A.S. (2011) Effect of different rates of farm yard manure and plant spacing on growth; yield and quality of Jerusalem artichoke plants under sandy soil conditions. J. Production, Mansoura Univ., 2(9), 1123-1135.

Association of Official Agricultural Chemists (A.O.A.C.) (1992) In: "Official Methods of Analysis", $12^{\text {th }}$ ed., the A.O.A.C., Washington D. C., U.S.A.

Chen, P. S., Toribara, T. Y. and Warner, H. (1956) Assay of inorganic phosphate, phosphate, total phosphate and phosphatases. Analysis Chemistry, 28, 1756.

Cooke, B.M. (2006) Disease assessment and yield loss.In: Cooke B. M., D. Gareth Jones and B. Kaye (Ed.), THE EPIDEMIOLOGY OF PLANT DISEASES. Springer. Netherlands, $2^{\text {nd }}$ ed., 43-80.

Cúndom, M.A., Gutiérrez, S.A. and Cabrera, M.G. (2013) Occurrence of Sclerotium rolfsii causing collar rot to Peperomia glabella in Argentina. Summa Phytopathology, Botucatu, 39 (2), 42. 
Dauda, S.N., Ajayi, F. A. and Ndor, E. (2008) Growth and yield of water melon (Citulluslanatus) as affected by poultry manure application. J. Agric. Soc.Sci., 4,121-124.

Davis, R.F., Smith, F.D., Bernneman, T.B. and McLean, H. (1996) Effect of irrigation on expression of stem rot of peanut and comparison of aboveground and belowground disease rating. Plant Disease, 80,1155-1159.

Eifediyi, E.K.,Remison, S.V. and Okaka, V.B. (2010) Effect of different organic manure on the dry matter components of cucumber varieties. 8 (5),16-22.

EL-Hady, O.A., Abo-Sedera, S.A., Basta H., ElSaied, A.H. and El-Saied, H. (2012a)The role of rice straw-based hydrogels on some soil microorganisms strains. Bio. 1, 78-84.

EL-Hady, O.A., Shaaban, S.M. and El-Dewiny,Camilia, Y. (2010) The conditioning effect of composts or/ and water absorbent polymers on some physiobiochemical properties of a sandy calcareous soil after cucumber plantation. Egypt J. Soil Sci. 50 (1), $51-69$.

EL-Hady, O.A.,Shaaban, S.M.,Wanas, Sh. A. (2012b) Effect of hydrogels and organic composts on soil hydro-physical properties and in production of tomato. Acta Hort., 933, ISHS: 115- 122.

El-Sharkawy, Z.A.(2007) Response of Dasheen to different organic fertilizer sources and rates under newly reclaimed sandy soil conditions. Ann. Agric. Sci., Moshtohor, 45 (4), 1651-1661.

El-Sirafy, Z.M.,Abbady,Khadra, A., El-Ghamry, A.M. and El-Dissoky, R.A. (2008) Potato yield Quality, Quantity and Profitability as affected by soil and foliar potassium application. Res. J. Agric. And Biol. Sci. 4 (6), 912-922.

Enujeke, E.C.,Ojeifo, I.M. and Nnaji, G.U. (2013) Residual effects of organic manure and inorganic fertilizer on maize grain weight and some soil properties in Asaba area of delta state. International J. Advanced Biol. Res. 3 (3), 433-442. Society for Sci. and Nature, India.

Ewulo, B.S., Ojeniyi, S.O. and Akanni, D. A. (2008) Effect of poultry manure on selected soil physical and chemical properties, growth, yield and nutrient status of tomato.African J. of Agric. Res. 3 (9), 612-616, http://www.academicjournals.org/ AJAR(accessed 2009 November 10).
FAO.(2008) Land and Plant Nutrition Management Service.http://www.fao.org/ag/agl/agll/.Accessed on November/ 15/2012.

Flores-Moctezuma H.E., Montes-Belmont, R., JiménezPérez, A. and Nava-Juàrez, R. (2006)Pathogenic diversity of Sclerotium rolfsii isolates from Mexico, andpotential control of southern blight through solarization andorganic amendments. Crop Protection, 25,195-201.

Franco, O.,Rigden, D.J.,Melo, F.R. and GrossideSa, H.F.(2002) Review: Plant $\alpha$ - amylase inhibitors and their interaction with insect $\alpha$ - amylases: Structure, function and potential for crop protection. Eur. $J$. Biochem., 26, 397-412.

Gautum, M. and Kolte, S.J.(1979) Control of Sclerotium of sunflower through organicamendments of soil. Plant and Soil, 53, 233-238.

GENSTAT. (2007) GENSTAT statistical packages GenStat Release 9.2 (PC/Windows) ( $9^{\text {th }}$ ed.). Lawes Agriculture Trust, Rothamsted Experimental Station, UK.

Graham, R.D.,Humphrius, J.M. and Kitchen, J.L. (2000) More enhanced cereals: a sustainable foundation for diet. Asia Pacific J. Clin.Nutr. 9 (Suppl.): S9.

Hafez, A. A. R.,Mikkelsen, D. S. (1981) Coloimetric determination of nitrogen for evaluation of nutrition status of rice. Soil and Plant Analysis 12 (1), 61-69.

HaggagL., F., Shahin, M.F.M., Mahdy, H.A., Atteya, A.K.G. and Hassan, H.S.A. (2015) Beneficial effect of NPK, pigeon manure tea and microbial fertilizers as soil application on growth of "Toffahi" and "Picual" olive seedlings. J. of Agric. Technology, 11 (7), 1565-1582.

Hassan A S.A. (2012) Effect of some characteristics of calcareous soils on available phosphorus in North Africa. M. Sc. Cairo Univ. Institute of African Res. and Studies. Dept. of Natural Res.

Hoseini, N. A.,Golchin, A. and Mohammadi, J. (2013) The effect of organic fertilizers and organic wastes on Aloe vera growth and development. Scholars Res. Library. 4 (8), 90-95.

Jenkins S.F. and Averre, C.W.(1986) Problems and progress in integrated control of southern blight of vegetables. Plant Disease, 70, 614-619.

John, L.W.,Jamer, D.B., Samuel, L.T. and Warner, L.W. (2004) Soil fertility and fertilizers: An introduction to nutrient Management. Person Educatio, Delhi, 106-153. 
Johnson, A.W., Minton, N.A., Brenneman, T.B., Burton, G.W.,Culbreath, A.K., Gascho, G.J. and Baker, S.H.(1999) Bahiagrass, corn, cotton rotations, and pesticides for managing nematodes, diseases, and insects on peanut. Journal of Nematolology, 31,191-200.

Junsopa,C.;Jogloy, S.,Saksirirat, W.,Songsri, P.,Kesmala, T.,Shew, B.B. and Patanothai, A. (2016) Inoculation with Sclerotiumrolfsii, cause of stem rotin Jerusalem artichoke, under field conditions. European Journal Plant Pathology, 146:47-58.

Karanatsidis, G. and Berova, M. (2009) Effect of organic $\mathrm{N}$ fertilizer on growth and physiological parameters in pepper plants (Capsicum annum L.). Biotechnal.\& Biotechnal. Eq. special edition on line 254-257.

Kwon, J. H., Jee, H. J. and Park, C. S. (2008) Occurrence of Bulb Rot of Allium victorialis var. platyphyllum Caused by Sclerotiumrolfsii in Korea.The Plant Pathology Journal, 24 (1), 90-92.

Mahmoud, E.,Abd El-Kader, N., Robin, P.,AkkalCorfini, N. and Abd El-Rahman, L. (2009) Effects of different organic and inorganic fertilizers on Cucumber yield and some soil properties. World J. of Agric. Sci., 5, 408-414.

Mansour, M.M., Salama, F.Z., Ali, M., Hadid, A. (2005) Cell and plant responses to $\mathrm{NaCl}$ in Zea Mays L. cultivars differing in salt tolerance, Gen. Appl. Plant Physiol., 31 (1-2), 29-41.

Massri, M. and Labban, L. (2014) Comparison of different types of fertilizers on growth, yield and quality properties of watermelon (Citrllus lanatus). Agricultural Sci., 5, 475-482.

Okabe I., Morikawa, C. andMatsumoto, N. (2000) Variation in southern blight fungus in Japan detected by ITS-RFLP analysis.http://ss.jircas. affrc.go.jp/engpage/jarq/34-2/okabe/34-2(3).htm.

Page, A.L.,Miller, R.H. and Keeney, D.R. (1982)" Methods of Soil Analysis", Part2, $2^{\text {nd }}$ ed., ASA and SSSA, Madison, Wiscansin, USA.

Punja, Z.K., Carter, J.D., Campbell, G.M. and Rossell, E.L.(1986) Effects of calcium and nitrogen fertilizers, fungicides, and tillage practices on incidence of Sclerotium rolfsii processing carrots. Plant Disease, 70, 819-824.
Rady, M.M., BhavyaVarma, C., and Howladar, S.M. (2013) Common bean (Phaseolus vulgaris L.) seedlings overcome $\mathrm{NaCl}$ stress as a result of presoaking in Moringa oleifera leaf. Scientia Horticulturae, 162, 63-70.

Ragab, M.E., Hamed, N.M. and El-Sharkawy, Z.A. (2008) Response of Jerusalem Artichoke (Helianthus tuberosus L. ) Plants to some Bio and organic fertilization treatments in the new reclaimed lands.Firest International Conference of Agric. Sci. Consohdated of Role the Research in Sustainability Agricultural Development plants, 13-15 October 2008, Fac. Agric., Aleppo Univ., Syria.

Ramamurthy, V. and Shivashankar, K. (1996) Residual effect of organic matter and phosphorus on growth, yield and quality of maize ( Zea mays). Indian Journal of Agronomy, 41, 247 - 251.

Sadeghi, H. (2010)The effects of different salinity levels on some important physiological characteristics of two wheat cultivars. $11^{\text {st }}$ Iranian Crop Science Congress. 3704p.

Sennoi, R., S. Jogloy, W. Saksirirat and A. Patanothai (2010) Pathogenicity test of Sclerotiumrolfsii a causal agent of Jerusalem artichoke (Helianthus tuberosus L.) stem rot. Asian Journal of Plant Science, 9(5), 281-284.

Taga, M.S., Miller E.E.and Pratt, D.E. (1984) Chia seed as a source of natural lipid antioxidants. JAOCS $\mathbf{6 1}$, 928-931.

Wakui, Y. (2009) Organic farming technology in Japan. Pilot project for better farm income by organicbased vegetable production.Koibuchicollege of Agriculture and Nutrition, MITO.

Winton, A.L. and Winton, K.B. (Ed.) (1985) The Analysis of Foods. John wiley and sons. Inc. London.85 7.P.

Žaldariene, S., Kulaitiene, J. and Černiauskiene, J. (2012) The quality comparison of different Jerusalem artichoke (Helianthus tuberosus L.) cultivars tubers. Žemes UKIO MOKSLAI. 19 (4),268-272.

(Received: $9 / 11 / 2018$; accepted:24/12/2018 ) 


\section{تأثير مخاليط الاسمدة العضوية علي أداء ومرض عفن الساق في نباتات الطرطوفة تحت ظروف الإجهاد}

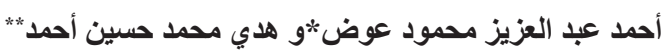

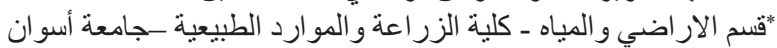

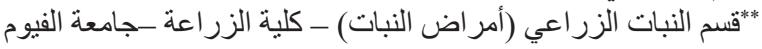

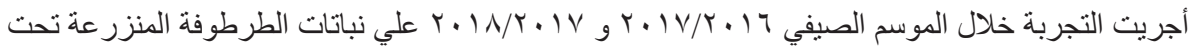

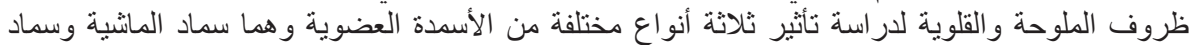

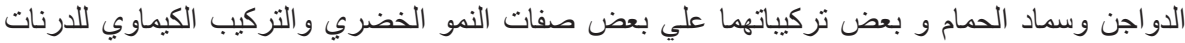

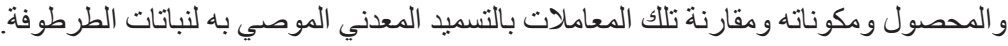

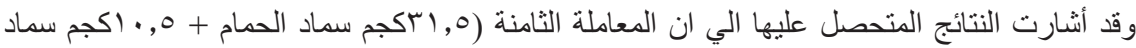

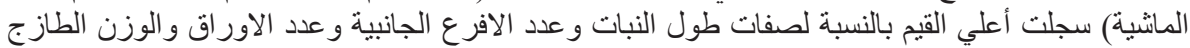

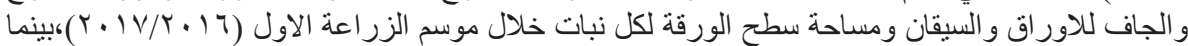

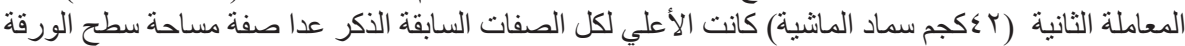

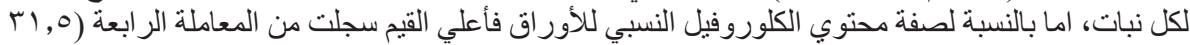
كجم سماد الماثشية + 0, • ( كجم سماد الدو اجن) تليها المعاملة الثالثة (ب كـ كجم سماد الحمام) في كلا الموسمين. اما بالنسبة لتركيز ات بعض العناصر الثقيلة في الدرنات، فوجد أن أقل محتوي من عنصري الكبري الكادميوم

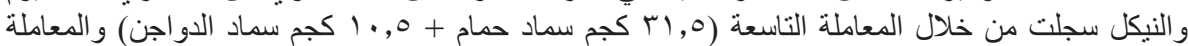

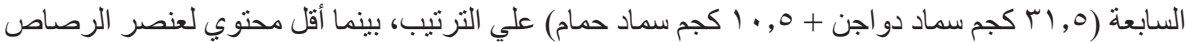

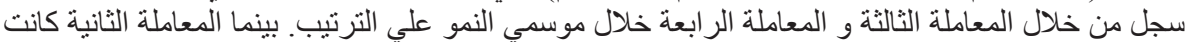
الاقل في النسبة المئوية لحدوث الماملة الصنابة

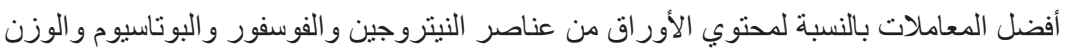

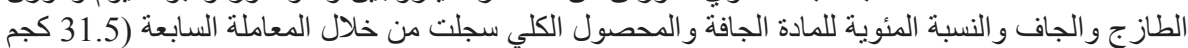

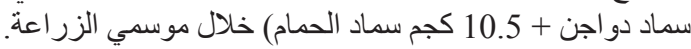

